\title{
Algılanan Liderlik İletişiminin İş Performansı ve İş Tatminine Etkisi: 4 ve 5 Yıldızlı Otel Çalışanları Üzerine Bir Araștırma
}

\author{
Serdar ÇÖP*, Ali DOĞANAY**
}

Öz

$\mathrm{Bu}$ araştırma otel işletmelerinde liderlerin astlarıyla kurdukları iletişimin onların iş tatminini ve performansını hangi ölçüde değiştirdiğini ortaya koymak ve sonuçlarını tartısmak amacyyla gerçekleștirilmiștir. İstanbul'da faaliyet gösteren 4 ve 5 yıldızlı otel işletmelerinde çalıșan 280 kiși araştırmaya katılmış, yapılan analiz neticesinde lider iletişim algısının çalışanların performans ve iș tatmini üzerinde etkisi olduğu sonucuna ulașlmıștır. Çalıșan profilinin giderek değiștiği düşünüldüğünde, otellerde görev alan lider veya yöneticilerin, 'lider iletișimi' kavramını dikkate alarak tutum ve davranış sergilemesi gerektiği ifade edilebilir.

Anahtar Kelimeler: Turizm, Otel İşletmeleri, Alglanan Lider İletişimi, İş Tatmini, İş Performans

\section{The Effect of Perceived Leadership Communication on Job Performance and Job Satisfaction: A Study on 4 and 5 Stars Hotel Businesses}

\begin{abstract}
This study was carried out to determine the extent to which the communication of the leaders or managers in the hotel business with the subordinates changed their job satisfaction and performance and to discuss the results. For this purpose, the scale containing the variables was applied to 280 employees in 5 and 4 star hotels operating in Istanbul. As a result of the analysis, it has been concluded that the leader communication perception has an effect on the performance and job satisfaction of the employees.

Keywords: Tourism, Hospitality Businesses, Perceived Leadership Communication, Job Satisfaction, Job Performance.

\section{Giriş}

İş hayatında hizmet sektörü çalışanlarının sahip olduğu yetkinlikler, iş performansı, örgüt performansı, iş tatmini gibi birçok konuyu etkilemektedir (Erkuş \& Günlü, 2009, s. 19). Iş̧letmeler, kâr elde etmek, varlıklarını sürdürmek ve sosyal sorumlulukgörevlerini yerine getirmekiçin yoğun rekabet ortamında zorlu bir mücadele vermektedir. Maddi yatırımların yanında, çalışanlarına değer veren işletmeler onların eğitimi ve gelişimi için de bir takım yatırımlar yapmaktadırlar.
\end{abstract}

\section{Özgün Araștırma Makalesi (Original Research Article) \\ Geliş/Received: 23.05 .2019 \\ Kabul/Accepted: 09.08.2019 \\ DOI: https://dx.doi.org/10.17336/igusbd.568236}

* Dr. Öğr. Üyesi, İstanbul Gelişim Üniversitesi, Uyg. Bil. YO, Gastronomi Böl., İstanbul, Türkiye, E-posta: scop@gelisim.edu.tr ORCID ID https://orcid.org/0000-0002-1101-5676

${ }^{* *}$ Dr. Öğr. Üyesi, İstanbul Gelişim Üniversitesi, Uyg. Bil. YO, İşletme Bilgi Yönetimi Böl., İstanbul, Türkiye, E-posta: adoganay@gelisim.edu.tr ORCID ID https://orcid.org/0000-0003-4036-9737 
Çalışanlardan en fazla verimi almak onların duygularına hitap etmekten de geçmektedir. Bu bakımdan çalışanları organizasyonun bir parçası haline getirerek belirlenen hedeflere yönlendirecek liderlere duyulan ihtiyaç her geçen gün artmaktadır (Eryeşil \& İraz, 2017, s. 130). Bu noktada liderlerin çalışanlarla iletişim kurarken kullandığ tarz da önem kazanmaktadır. Çalışanların davranışları liderin kullandığı sert veyayumuşakiletişimden etkilenmekte ve iş çıktları buna göre șekillenebilmektedir. Çalıșanların fikirlerini paylașırken bir liderin onları dinliyor olması önemlidir. Dinlenilmediğini fark eden çalışanlar bir süre sonra fikir önerisinde de bulunmazlar, bu da yaratıcılıklarını ve uzmanlıklarını kullanmayacakları sonucunu doğurur. En etkili liderler, ne zaman susmaları gerektiğini ve ne zaman konuşmaya bașlayacaklarını bilen liderlerdir. Bu bakımdan çalıșan yönetici ilișkilerinin diğer kavramlarla da ilișkisi olduğu düșünülmektedir. Örgütsel davranış alanında iş tatmini ve performans kavramının ișten ayrılma, yabanclașma, verimlilik, iș kazaları gibi önemli örgütsel kavramlarla yakın ilișkisi nedeniyle incelenmeye değer görülmüștür (Kök, 2006, s. 194). Otel işletmelerinde çalışanların tutum ve davranışlarının müșteriye yansımaları düșünüldüğünde, çalıșan tutum ve davranışlarının yönetilmesi daha da önemli hale gelmektedir. Otellerin en büyük gider kalemlerinden biri olan çalıșanların, performansları ve iș tatminlerinin arttırılması karlılık için önemlidir. Karlılı ile birlikte ișletmelerin marka değerleri, sektörde rakiplerinin önünde yer almaları çalıșanların performans ve tatminine bağlıdır. Buradan otellerde liderlerin iletişim kanallarını açıktutup, doğruyöneterekperformansve tatmin sağlaması önem arz etmektedir.

\section{Kavramsal Çerçeve Liderlik Illetişimi}

İnsanların bireysel, toplumsal, örgütsel, siyasal ve ekonomik hayatlarında önemli bir yer tutan liderlik kavramı üzerinde birçok çalışma yapılmış olmasına rağmen uzlașılmış bir tanımlama bulunmamaktadır (Bakan, 2009, s. 140).

Liderlik, takipçileri istekli bir şekilde amaçlara ulaştırmak için harekete geçirme ve etkileme süreci olarak tanımlanmaktadır (Newstrom \& Davis, 1997, s. 200). Başka bir ifadeyle liderlik, lider ve izleyenler arasındaki bağı ve etkileșimi ifade etmekte ve bir organizasyonda çalışanların yöneticilerinin yapılmasını istediği faaliyetleriyapmaları anlamına gelmektedir (Yammarino \& Fred Dansereau, 2009, s. 89). Lider, çevresindekilere ellerinden gelen bütün gayreti sarf ettirerek, yapılacak işin en iyisini yapmaları için motive edebilen kișidir. Liderlik vasfi bir kişi de doğuştan bulanabileceği gibi bu özellik sonradan da öğrenilebilir (Thombson, 2002, s. 133). Turizm sektöründe ișletmelerin belirledikleri hedeflerine ulașmaları için bir arada bulunan çalıșanları yöneten ve yönlendiren, koordine eden faaliyetleri planlayan liderler örgütler için birer vazgeçilmezdir. Liderler ile çalıșanlar arasındaki etkileșim onların davranıșları üzerinde etkili olmaktadır. Güçlü bir lider-çalışan ilişkisi hem liderin hem çalışanın hem de işletmenin performansına katkı sağlayacaktır (Schriesheim, Castro, Zhou \& Yammarino, 2001, s. 515).

Liderlik iletişimin ilham kaynağ olduğu ifade edilmektedir (Smith, Figgins, Jewiss \& Kearnery, 2018, s. 222). İletişim Oskay (2016) tarafindan, insanın varlı̆ğmı devam ettirmesinin ürünü ve değişimlere uğrayan insana özgü bir olgu olarak tanımlamıştır (Oskay, 2016, s. 7). Illetişim, örgütlerde çalışanlar arası insani ilişkilerin oluşmasında ve işlerin sağlıklı bir biçimde yönlendirilmesinde önemli bir konuma sahiptir. İletişim sayesinde yöneticiler ve çalışanlar görüş birliği ve ortak anlayışa varmakta ve belirlenen hedeflere ulaşmak için iş birliği yapmaktadırlar. Çalışanların organize bir biçimde hareket etmesi onların güçlerini ortaya çlkaracak biçimde yapılandığını göstermektedir. Modern çalışma yaşamı, grup ve birey biçiminde örgütlenmiş insanların etkili iletişim ağları ile olușturulmuștur (Aslanbay, 2018).

Örgütsel açıdan bakıldığında iletişimin örgüt içinde yürütülen bütün faaliyetlerinin arka planındaki faktör olduğu görülmektedir. Bu nedenle lider iletişiminin “örgütü bir arada tutan sosyal bir yapış̦trıcı” olduğu kabul edilmektedir (Baron \& Greenberg, 2000, s. 469). 
İnsanlar iletişim kurarken ortak birikimlerine ait göstergelere başvururlar. $\mathrm{Bu}$ göstergelerden meydana gelen çeşitli iletişim biçimleri bulunmaktadır (Bıçakçı, 2006, s. 23). Örgütlerdeki iletişim sistemleri de genel iletişim düzeninden ayrı düşünülemez. Örgütler hem iç hem de dış çevrelerinde sürekli etkileşim içerisinde bulunan sistemlerdir. Organizasyonların faaliyetlerinin verimli bir biçimde yürütülebilmesi ve belirlenen amaçlara etkin bir șekilde ulaşabilmesi için iç ve dıș ilişkilerin sağlkklı olması gerekmektedir. Genel bir ifadeyle, örgütsel bir fonksiyon olarak değerlendirilen iletișim örgütün iç ve dıș çevresinde bulunan bölümler ve kișiler arasındaki ilișkileri birtakım kanallarla düzenlemekte ve kontrol altında tutmaktadır. İletișim çalışanlar ve bölümler arasında ilişkiler kurulmasını ve bunların geliştirilmesini sağlamaktadır (Tutar vd., 2003, s. 70). Bir örgütte yöneticinin etkin ve başarılı olabilmesi çalışanlarının bașarısıyla doğru orantılıdır. Elbette bu ilișkiyöneticinin çalıșanlarıyla sorunsuz ve eksiksiz sağlamış olduğu bir iletişim biçimiyle gerçekleșmektedir. Benzer șekilde bu süreç eșit seviyedeki çalıșanlar için de geçerlidir. Özetle iletişim hem çalıșanların hem de yöneticilerin üzerinde önemle durması gereken süreçlerin bașında gelmektedir (Koçel, 2005, s. 522). İletișimin birçok ișlevinin yanı sıra yürütülen faaliyetin niteliğine olan etkisi düşünüldüŭünde yönetim kademesi ve liderlerin performansı üzerinde de etkisi olduğu söylenebilir (Robbins \& Coulter, 2003, s. 282). İșletmelerin kriz dönemlerinde liderlik iletişiminin ayrıca bir öneme sahip olduğu ifade edilmektedir (Stam, Knippenberg, Wisse, Pieterse, 2018, s. 2883).

Organizasyonlarda yöneticiler ile çalıșanlar arasında gerçekleșen iletișim, genellikle iş ve sosyal ihtiyaçları gidermek amacıyla oluşmaktadır. Bu bakımdan işe yönelik iletişim tarzlarında emir verme, bilgi verme ve geribildirimler ile olumlu veya olumsuz durumlar yer alır. Bu iletişim biçimleri çalışanların iş tatminleri üzerinde etkili olabilmekte; bu iletişimin kalitesinin artması ise çalıșanların performans, iş tatmini ve motivasyon düzeylerini yükseltebilmektedir (Mustaffa vd., 2010, s. 16-20).

Bunun yanında liderlerle çalıșanlar arasında kurulan nitelikli ve etkin bir iletişim sisteminin çalışanların örgütsel bağllıklarını ve örgütte kalma isteklerini arttırdığı, işgücü devir hızını düşürdügü ve muhtemel sorunların ilk çıtığı anda çözüme kavuşturduğu söylenebilir. (Taplin ve Winterton, 2007, s. 13). Ergün (2018, s. 189) tarafindan yapılan çalışmada da liderlerin bilgi desteğinin iș tatminini önemli derecede etkilediği tespit edilmiștir. Çalıșanlar liderlerin iletişim tarzlarından etkilendikleri bilinmektedir. Iletilmekistenen konuların içeriği,örgütün iletișim sistemi ve bu sistemin işleyişini alglama biçiminin olumlu ya da olumsuz olmasının çalsşanların iş tatminini ve performansını etkilediği görülmüștür (Gray ve Laidlaw, 2002, s. 213).

\section{İș Performansı}

Performanssözcüğü, belirli bir zaman dilimindeüretilen mal veya hizmetmiktarı biçiminde ifade edilmekte ve literatürde işlevi bakımından "etkinlik", "verim", "çıkt" kavramlarıyla, ayrıca kişinin yeteneği ve motivasyonu arasındaki etkileșimin bir neticesi șeklinde tanımlanmaktadır (Torrington ve Hall, 1995, s. 316, Kalkandelen, 1997, s. 154).

Örgütsel davranış bakımından performans olgusu, çalışanların belirlenen örgütsel amaçlara ulaşmak için görevleri kapsamında olan işlemlerin sonucunda elde edilen ürün olarak ifade edilmektedir. Bu ürün mal veya hizmet olabileceği gibi düşünce tarzında da olabilir (Başaran, 1991, s. 179). Bir başka deyişle; görev kapsamında önceden planlanan ölçütleri karșllayacak şekilde, görevin tamamlanması ve hedefe ulaşılması için meydana çıkarılan mal hizmet ya da düşüncedir şeklinde tanımlanmaktadır (Pugh, 1991, s. 7-8).

Otel işletmelerinde performansın koordineli bir şekilde yönetilmesi başarının anahtarıdır. Performans yönetimi ile bireylerin ve grupların sorumluluk üstlendikleri bir kültür olușturulması, becerilerin ve örgütün etkinliklerinin sürekli bir biçimde iyileștirilmesinin amaçlandığı söylenebilir (Bolton, 1997, s. 248, Cemaloğlu, 2002, s. 183).

Performans yönetimi, belirlenen hedeflere ulașmayla ilgili performansı inceleyen, geri bildirimin önemini ortaya koyan yönetim biliminin bir dalıdır. Çalışanların iş davranışları ile 
Serdar Çöp, Ali Doğanay, "Algılanan Liderlik İletişiminin İș Performansı ve İş Tatminine Etkisi: 4 ve 5 Yıldızlı Otel Çalışanları Üzerine Bir Araştırma”, İstanbul Gelișim Üniversitesi Sosyal Bilimler Dergisi, 7 (1), Nisan 2020, ss. 34-49.

performanslarının tanımlanması, güçlendirme ve değerlendirme konularıyla bütünleștirilmiş bir süreçtir (Armstrong, 1996, s. 262, Cumming ve Worley, 1997, s. 370). Performans yönetimi, bireylerin, takımların ve örgütlerin daha etkin ve verimli bir hale gelmesini hedeflemekte, gerekli yeterlilikler, bilgi ve beceri ile çalışma ve geliștirme kavramlarını konu edinmektedir. Planlara, koşullara, amaçlara bağlı kalarak sürekli inceleyerek, geliştirme ve öğrenme konuları üzerine odaklanmaktadır (Armstrong, 1996, s. 261; Canman, 1995 ). Performans yönetimi ile ilgili süreç içerisinde üyeler hiyerarşik bir kademeden ziyade ekip üyesi olarak görülüp, sorumluluklar geliştirme planlarına ve beklentilere dayandırılmaktadır. Yöneticiler ile üyeler arasındaki etkileşim normal iletişimin bir parçası olarak kabul edilmektedir. Bu süreç dönemsel bir sürecin dışında devamlı bir süreç olup, yılda bir kere yapılan bir incelemeye dayandırılmaz; performansın iyileștirilmesine odaklanarak yeterliliğin ve potansiyelin geliştirilmesini amaçlar (Armstrong, 1996, s. 261).

Otelișletmelerinde personelyönetimi birimininyerini insan kaynakları birimininalmasıyla, çalıșanların performansı tespit edilmeye başlanmıștir. Otel ișletmelerinde $360^{\circ}$ performans değerleme sistemi, balance skor kart uygulaması gibi performans değerleme yöntemleri kullanılmaktadır. Bazı kaynaklarda başarı değerlendirme olarak da adlandırılan performans değerlendirme, insan kaynakları yönetiminin önemli fonksiyonları arasında bulunmaktadır. Genel olarak performans değerlendirme sistemi ile bireyin, grubun veya örgütün bir konu hakkındaki etkinliğini bazı kriterlere göre analiz ederek başarı düzeyini belirlemek amacıyla çalışmalar yapılmaktadır (Ersen, 1997, s. 113; Erdoğan, 1991, s. 155). Performans değerlendirme, bir değerlendiricinin önceden belirlenmiş bazı standartlarla karşılaștırarak ve ölçerek, çalışanların ișteki performansını değerlendirmesi süreci olarak ifade edilebilir (Palmer, 1993, s.9). Performans değerlendirme, belirlenen görev ve iș tanımları kapsamında çalışan kişilerin, iş gerekliliklerini ne ölçüde gerçekleștirdiğinin tespit edilmesi bakımından önem taşımaktadır (Fındıkçı, 2000, s. 297).

Çalışma sonuçlarının iyileștirilmesi için gerekli verilerin toplanması ve yayılması süreçlerini kapsayan performans değerlendirme; çalışma gruplarına ve bireylere performans geri bildirimi sağlayan insan kaynaklarıyönetimi girişiminin temelini teșkil etmektedir. Bu bakımdan performans değerlendirme bireyin ya da örgütün güçlü yanları, başarıları ya da bașarısızlılarını değerlendirmeye alan sistematik bir süreç olarak ifade edilebilir. Diğer yandan mesleki gelişim ve insan kaynağının çeşitliliğine de yardımcı olmaktadır (Helvacı, 2012, s.158). Otel işletmelerinde performans göstergelerinin belirlenerek, performans sonuçlarının ortaya konulması neticesinde, iş görenlerin kendilerini geliștirmeleri, güçlü veya zayıf yönlerinin farkına varmaları söz konusudur. Otel işletmelerinde her bir çalışanın performansının adil ve şeffaf göstergeler ile tespit edilmesi, bu performansta etkili olan unsurların belirlenmesi önem arz etmektedir.

\section{İş Tatmini}

Otel işletmelerinde rakiplerine karşı en büyük avantajı insan kaynakları bakımından güçlü işletmeler sağlamaktadır. Çünkü işletmelerin maddi kaynakları birtakım finans kuruluşları vasıtasıyla sağlanabilir. Ancak aynı durum insan kaynakları açısından geçerli değildir. Çünkü temin edilmesi ve yetiștirilmesi uzun ve daha maliyetli olabilmektedir. Yoğun tempolu ve stresli bir çalışma alanı olan otel işletmelerinde işgören devir hızı oranı yüksek olduğunda işletme yönetimleri çalışanları elinde tutmak için çeşitli yöntemler aramaktadırlar. Bu yöntemler çeşitlilik gösterse de en önemli ve maddi olmayan kaynakların başında gelen unsurlardan bir tanesi de iş tatminidir (Kaya, 2007, s. 369).

İş tatmini, çalıșanların yürüttüğü görevlere karşı gösterdikleri duygusal tepkiler olarak tanımlanmaktadır. Bu tepkiler olumlu ise iș tatmini, olumsuz ise iş tatminsizliği olarak ifade edilmektedir (Vroom, 1967, s. 99). İș tatmini konusu sosyal bilimciler tarafindan en çok ilgi çeken konulardan biri olmuștur. Cranny vd. 1992 yılında bu konuda yapılan çalışmaların sayısının 5000'in üzerinde olduğunu ifade etmiștir. Bir diğer çalıșma da Oshagbemi tarafindan yapılmış ve bildiri ile tüm makalelerin birlikte 7000’e çlkacağı belirtilmiștir (Oshagbemi, 1997, s. 389-400). 
İş tatmini çağdaş yönetim anlayışının en önemli konularından biri olarak görülmektedir. Yönetsel ve davranıșsal sonuçları bakımından önem taşıyan iș tatmini/tatminsizliği konusu, bir örgütte işlerin iyi gidip gitmediğinin en önemli göstergelerinden biridir. İş tatmini sağlanamayan örgütler, vücudun hastalıklara karşı düșeceği tehditlere benzer durumlar yaşamaktadırlar. Örgütün bağışıklığ zayıflamayabilmekte, hem dış hem de iç tehditlere karșı verilen tepkiler düşmekte hatta yok olabilmektedir. Benzer şekilde fiziksel ve zihinsel sağlıkla iş tatmini arasında da yakın bir ilişki bulunmaktadır. Çalışanların birçok fiziksel ve zihinsel davranış bozukluklarının altında yaşadıkları iş tatminsizliğinin yattığ bilinmektedir. Bu durum duygusal ve sinirsel bir takım bozukluklara sebep olmakta, iştahsızlık, uykusuzluk, ruhsal çöküntü ve hayal kırıklğına neden olabilmektedir. Çalışanların hayatında birçok kısır döngüye sebep olan iş tatminsizliğinin iş hayatında mutsuzluğun önemli bir nedeni olduğu söylenebilir. (Miner, 1992, s. 119).

Çalıșanların fiziksel ve ruhsal sağlı̆̆nı, organizasyonun verimliliğini ve çalıșma bașarısını etkilemesi bakımından iş tatmininin yadsınamayacak bir önemi vardır. Yarattı̆ı sonuçlar itibariyle iș tatmini hem bireysel hem örgütsel hem de toplumsaldır. Bu bakımdan varlığı çok istenen ancak her zaman elde edilemeyen bir olgudur. Olumlu çalıșma koșullarını olușturması bakımından iș tatmini yöneticiler tarafından da çok arzu edilen bir durumdur. İş tatminsizliğinin görüldüğg̈ örgütlerde ise iş yavaşlatma, verimsizlik, disiplinsizlik ve devamsızlık gibi istenmeyen davranışlar görülebilmektedir (Davis, 1988, s. 95). Otel işletmeleri bakımından ise iş tatmini özellikle üretim ve tüketimin eş zamanlı olarak gerçekleşmesi nedeniyle daha da önem kazanmaktadır. Otel işletmelerinde çalışanların yaptkkları işten tatmin olmaları, birebir ilişki içerisinde oldukları müşterilere mutlaka yansıyacaktır. İşinde tatmin olan çalıșan müșteriyi tatmin için elinden geleni yapacaktır. Otel işletmelerinde işinden tatmin olmayan çalsşanın, kritik önem arz eden görevlerde, örneğin; kathizmetlerinde ya da mutfakta çalıșanların hijyen ve sanitasyona; ön büroda çalışanların satış arttırmaya; insan kaynaklarında çalışanın yasa ve yönetmeliklere gereken dikkat ve ciddiyeti göstermeyeceği ifade edilebilir. Buradan, otel işletmelerinde çalışanların iş tatmini için ekonomik, sosyal ve psikolojik unsurların hassasiyetle ele alınması ve incelenmesi gerekmektedir.

\section{Araștirma}

\section{Araştırmanın Amacı}

Çalışanlarla liderleri arasında gerçekleșen iletişim ve onların iletişime iliş̧in algıları, işletmelerin başarısında önemli bir rol oynamaktadır. Liderlerin sergilediği davranışa göre iletişim tarzları farklılaşabilmektedir. Liderin sergilediği her farklı iletişim tarzı çalışanlar üzerinde farklı etkiler yaratmakta, çalışanların davranışları üzerinde etkili olmaktadır (Sneidervd. 2015, s. 192). Bu araștırma ișletmelerin en önemli kaynaklarından biri olan insan kaynağını oluşturan çalışanların, liderlik iletişim algısının iș tatminine ve iș performansına etkisi olup olmadığını belirlemek amacıyla yapılmıştır.

Araștırmanın Modeli ve Hipotezler

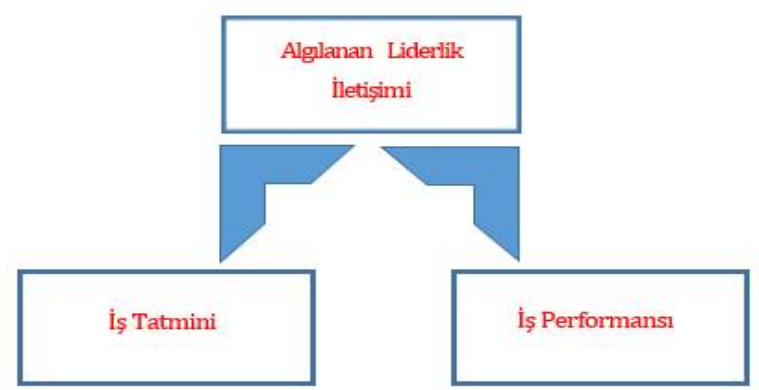

Araştırmanın Modeli 
Serdar Çöp, Ali Doğanay, "Algılanan Liderlik İletişiminin İş Performansı ve İş Tatminine Etkisi: 4 ve 5 Yıldızlı Otel Çalışanları Üzerine Bir Araștırma”, İstanbul Gelișim Üniversitesi Sosyal Bilimler Dergisi, 7 (1), Nisan 2020, ss. 34-49.

vardır.

Çalışmanın amacı doğrultusunda belirlenen hipotezler aşağıdadır.

$\mathbf{H}_{1}$ : Çalıșanların lider iletișim algısının iș tatmini üzerinde istatistiki açıdan anlamlı etkisi etkisi vardır.

$\mathbf{H}_{2:}$ Çalıșanların lider iletişim algısının iş performansı üzerinde istatistiki açıdan anlamlı bir

\section{Araştırmanın Evren ve Örneklemi}

Araștırma 4 ve 5 yıldızlı otel işletmelerinde gerçekleştirilmiştir. Araştrmaya İstanbul'da faaliyet gösteren 280 otel ișletmesi çalışanı katılmıștır. Araștırmaya katılan çalışanlardan yüz yüze anket tekniği kullanılarak veriler elde edilmiștir. Dikey yönlü yönetim yapıları ve kurumsal yönleri araștırmanın otel ișletmeleri üzerinde yapılmasında etkili olmuștur. Ayrıca yüz yüze iletişimin, emek yoğunluğunun diğer sektörlere göre fazlaca oluşu da araștırmanın otellerde yapılmasında dikkate alınmıştır.

\section{Veri Toplama Aracı}

Algılanan Liderlik İletişimi Ölçeği: Algılanan liderlik iletişimini ölçmek için Schneider vd. (2014) tarafından yapılan çalışmadan alınarak Türkçe'ye çevirisi yapılan alglanan liderlik iletișim ölçeği (the perceived leadership communication questionnaire (PLCQ)) kullanılmıștır. 5'li Likert tipinde olan ölçekte tepki ifadeleri, "kesinlikle katilmıyorum, katılmıyorum, emin değilim, katıllyorum ve kesinlikle kathlıyorum" șeklinde tasarlanmıștır (Schneider, 2015, s. 192).

İs Tatmini Ölçeği: İș tatmini ölçmek amaciyla Weiss vd. tarafindan 1967'de geliştirilen "Minnesota iş tatmini ölçeği" kullanılmıştır. Ölçek 20 ifade ve 2 faktörden oluşmaktadır. 5'li Likert tipinde olan ölçekte tepki ifadeleri; "hiç memnun değilim, memnun değilim, ne memnunum ne memnun değilim, memnunum, çok memnunum" șeklindedir (Weiss vd., 1967, s. 90).

Performans Ölçeği: Bireysel iș performansı literatürde bazı sınıflandırmalar yapılarak ele alınmıștır. Bu araștırmada çalıșanların performansı genel olarak değerlendirilmiștir. Bu amaçla Kirkman \& Rosen (1999) ile Sigler \& Pearson (2000) tarafindan kullanılan ve Cöl (2008) tarafindan Türkçe'ye çevrilen iş performansı ölçeği tercih edilmiștir. Ölçeğin tepki kategorileri "hiçbir zaman, çok nadir, ara sıra, çoğu zaman ve her zaman" şeklindedir (Çöl, 2008, s. 41).

\section{Analiz Yöntemi}

Toplanan veriler için "yüzde", "frekans", "bağımsız örneklemler için t-testi", "tek faktörlü varyans (Anova) analizi", "Tukey (HSD) testi", "korelasyon", "basit ve hiyerarşik regresyon", analizleri kullanılmıștır. Ayrıca araştırmada kullanılan ölçeklerin gerek ulusal gerek uluslararası literatürde çok defalar geçerlilik ve güvenilirlik çalıșmaları yapılmıștır. Bu araștırmada güvenilirliğe ilişkin olarak yapılan Cronbach Alpha analizi sonucunda kullanılan ölçeklerin sosyal bilimler açısından oldukça güvenilir olduğu belirlenmiştir. Liderlik iletişimi ölçeği için alpha katsayısı 0,96; performans ölçeği 0,91 ; iş tatmini ölçeği 0,94 olarak tespit edilmiştir. 


\section{ARAŞTIRMAYA DAİR BULGULAR}

Tablo 1. Araștırmaya Katılanların Bireysel Özelliklerine İlişkin Yüzde ve Frekans Dağılımları

\begin{tabular}{|c|c|c|c|c|c|c|c|}
\hline \multicolumn{2}{|c|}{ Kişisel Bilgiler } & f & $\%$ & \multicolumn{2}{|c|}{ Kişisel Bilgiler } & \multirow{2}{*}{$\begin{array}{c}\mathbf{f} \\
128 \\
\end{array}$} & \multirow{2}{*}{$\begin{array}{c}\% \\
45,7 \\
\end{array}$} \\
\hline \multirow{2}{*}{ Cinsiyet } & Kadın & 106 & 37,9 & \multirow{2}{*}{$\begin{array}{l}\text { Medeni } \\
\text { Durum }\end{array}$} & Evli & & \\
\hline & Erkek & 174 & 62,1 & & Bekâr & 152 & 54,3 \\
\hline \multirow{6}{*}{ Yaş } & 25 yaș altı & 37 & 13,2 & \multirow{5}{*}{$\begin{array}{l}\text { İşletmedeki } \\
\text { Görev Süresi }\end{array}$} & 1 yıldan az & 40 & 14,3 \\
\hline & $26-30$ yaș & 66 & 23,6 & & $1-5$ yll & 131 & 46,8 \\
\hline & $31-35$ yaș & 64 & 22,9 & & 6-10 yll & 77 & 27,5 \\
\hline & $36-40$ yaş & 42 & 15,0 & & $11-15$ yıl & 20 & 7,1 \\
\hline & 41-45 yaș & 46 & 16,4 & & 15 yıl ve üzeri & 12 & 4,3 \\
\hline & $\begin{array}{l}46 \text { yaş ve } \\
\text { üzeri }\end{array}$ & 25 & 8,9 & \multirow{3}{*}{ Pozisyon } & İşgören & 186 & 66,4 \\
\hline \multirow{5}{*}{ Eğitim } & İlköğretim & 54 & 19,3 & & $\begin{array}{c}\text { Orta Kademe } \\
\text { Yönetici }\end{array}$ & 76 & 27,1 \\
\hline & Lise & 101 & 36,1 & & $\begin{array}{l}\text { Üst Kademe } \\
\text { Yönetici }\end{array}$ & 18 & 6,4 \\
\hline & Önlisans & 57 & 20,4 & \multirow{2}{*}{ Yıldız Sayısı } & 4 Yildızlı & 145 & 51,8 \\
\hline & Lisans & 56 & 20,0 & & 5 Yildızlı & 135 & 48,2 \\
\hline & Lisansüstü & 12 & 4,3 & & & & \\
\hline
\end{tabular}

Araştırmaya katılan otel işletmesi çalışanlarının bireysel özelliklerine ilişkin yüzde ve frekans dağılımları Tablo 1'de gösterilmiștir. Araștırmaya katılanların cinsiyete göre dağılımında \%37,9'u kadınlar ve \%62,1'i erkekler oluşturmaktadır. Yaşa göre dağılımda ise \%23,6 ile 26-30 yaş aralığındaki katılımcllar en yüksek frekans değerine sahiptir. Oranlar değerlendirildiğinde sektörde genç çalışanların varlığı görülmektedir. Katılanların eğitim durumları incelendiğinde lise mezunlarının \%36,1 oranla çoğunluğu oluşturduğu, bunu \%20,4 ile önlisans mezunlarının, \%20,0 ile lisans mezunlarının \%19,3 ile de ilköğretim mezunlarının izlediği görülmektedir. Araștırmaya katılanların medeni durumlarındaki verilerde ise \%45,7'lik kısmın evli, \%54,3’lük kısmın ise bekar olduğu görülmüştür. Araştırmaya katılanların işletmedeki görev sürelerine bakıldığında $\% 46,1$ oranındaki katılımcı sayısının 1-5 yıllık bir çalıșma süresine sahip oluğu tespit edilmiștir. Araştırmaya katılanların \%51,8'i 4 yıldızlı, \%48,2'si ise 5 yıldızlı otel işletmelerinde çalışmaktadır. Elde edilen tüm bu verilerin turizm sektörünün istihdam yapısı ile uyumlu olduğu düşünülmektedir.

Tablo 2. Araştırmaya Katılanların Liderlik İletişimi, İş Performansı ve İş Tatmini Algısına İliş̧in Ortalama ve Standart Sapma Değerleri

\begin{tabular}{cccc}
\hline & $\mathbf{n}$ & $\bar{x}$ & s. s. \\
\hline Liderlik ̇̇letişimi & 280 & 3,37 & 1,18 \\
\hline İș Performansı & 280 & 4,53 & 0,68 \\
\hline İş Tatmini & 280 & 3,73 & 0,76 \\
\hline
\end{tabular}


Tablo 2'de araştırmaya katılanların değişkenlere verdikleri cevapların aritmetik ortalama ve standart sapma değerlerine ait bulgulara yer verilmiștir. Buna göre kathlımcların lider iletişim algısı ölçeğine vermiş oldukları cevapların ortalaması $X=3,37$, iş performansı ölçeğine vermiş oldukları cevapların ortalaması $X=4,53$, iş tatmini ölçeğine vermiş oldukları cevapların ortalaması ise $X=3,73$ olmuştur. Elde edilen verilerden iş performansı algısının oldukça yüksek olduğu, iş tatmininden kısmen memnun oldukları, liderlik iletişiminin geliștirilmesi gerektiği ifade edilebilir.

Tablo 3. Araştırmaya Katılanların Liderlik İletişimi, İş Performansı ve İş Tatmini Algısı Ille Cinsiyet Arasındaki Farklılığa İlişkin T Testi Sonuçları

\begin{tabular}{|c|c|c|c|c|c|c|}
\hline & & $\mathrm{n}$ & $\bar{x}$ & s. s. & $\mathrm{t}$ & $\mathrm{p}$ \\
\hline \multirow{2}{*}{ Liderlik İletișimi } & Kadın & 106 & 3,240 & 1,122 & \multirow{2}{*}{$-1,440$} & \multirow{2}{*}{0,151} \\
\hline & Erkek & 174 & 3,450 & 1,215 & & \\
\hline \multirow{2}{*}{ İș Performansı } & Kadın & 106 & 4,537 & ,6256 & \multirow{2}{*}{$-0,012$} & \multirow{2}{*}{0,99} \\
\hline & Erkek & 174 & 4,538 & ,7239 & & \\
\hline \multirow{2}{*}{ İş Tatmini } & Kadın & 106 & 3,442 & ,7879 & \multirow{2}{*}{$-5,154$} & \multirow{2}{*}{0,00} \\
\hline & Erkek & 174 & 3,907 & 6959 & & \\
\hline
\end{tabular}

Tablo 3’e göre araștirmaya katılanların lider iletişim algısı cinsiyete göre anlamlı farklıllk göstermemektedir. Erkek katılımcıların, kadınlara oranla lider iletişim algısının yüksek olduğu görülmüștür ( $p>0,05)$. İș performansı değiş̧kenine ait değerlerde de anlamlı bir fark görülmemiștir. İş tatmini değișkeninde ise cinsiyete göre anlamlı fark görülmüștür. Erkek katılımclların iş tatmini algisı kadın katılımclara göre daha yüksektir $(\mathrm{p}>0,05)$.

Tablo 4. Katılımcıların Liderlik İletişimi, İş Performansı ve İş Tatmini Algısı ile Medeni Durum Arasındaki Farklılığa İlișkin T Testi Sonuçları

\begin{tabular}{|c|c|c|c|c|c|c|}
\hline & & $\mathrm{n}$ & $\bar{x}$ & s. s. & $\mathrm{t}$ & $\mathrm{p}$ \\
\hline \multirow{2}{*}{ Liderlik İletişimi } & Bekâr & 152 & 2,625 & 1,053 & \multirow{2}{*}{$-15,80$} & \multirow{2}{*}{0,00} \\
\hline & Evli & 128 & 4,256 & 0,550 & & \\
\hline \multirow{2}{*}{ İș Performansı } & Bekâr & 152 & 4,360 & 0,832 & \multirow{2}{*}{$-4,921$} & \multirow{2}{*}{0,00} \\
\hline & Evli & 128 & 4,750 & 0,360 & & \\
\hline \multirow{2}{*}{ İș Tatmini } & Bekâr & 152 & 3,505 & 0,858 & \multirow{2}{*}{$-5,697$} & \multirow{2}{*}{0,00} \\
\hline & Evli & 128 & 4,000 & 0,523 & & \\
\hline
\end{tabular}

Tablo 4'e göre araştırmaya katılanların lider iletişim algısı medeni duruma göre anlamlı farklılık göstermektedir. Evlilerin, bekârlara oranla lider iletişim algısının yüksek olduğu saptanmıștır $(p>0,05)$. İs performansı değişkenine ait değerlerde de anlamlı bir fark görülmüștür. Evli katılımclların bekârlara oranla performans algları daha yüksektir (p>0,05). İş tatmini değişkeninde ise medeni duruma göre istatistiki açıdan 0,05 düzeyinde anlamlı bir farklılı tespit edilmiştir. Evli katılımcların iş tatmini algısının bekâr katılımcılara göre yüksek olduğu tespit edilmiștir ( $\mathrm{p}>0,05)$. 
Tablo 5. Araștırmaya Katılanların Liderlik İletişimi, İş Performansı ve İş Tatmini Algısı ile Çalışılan İşletmenin Yıldız Sayısı Arasındaki Farkııı̆ga İlişkin T Testi Sonuçları

\begin{tabular}{|c|c|c|c|c|c|c|}
\hline & & $\mathrm{n}$ & $\bar{x}$ & S. S. & $\mathrm{t}$ & $\mathrm{p}$ \\
\hline \multirow{2}{*}{ Liderlik İletişimi } & 4 yıldızlı & 145 & 2,996 & 1,141 & \multirow{2}{*}{$-5,795$} & \multirow{2}{*}{0,00} \\
\hline & 5 yıldızlı & 135 & 3,772 & 1,097 & & \\
\hline \multirow{2}{*}{ İș Performansı } & 4 yıldızlı & 145 & 4,451 & 0,704 & \multirow{2}{*}{$-2,202$} & \multirow{2}{*}{0,28} \\
\hline & 5 yıldızlı & 135 & 4,631 & 0,658 & & \\
\hline \multirow{2}{*}{ İş Tatmini } & 4 yıldızlı & 145 & 3,475 & 0,719 & \multirow{2}{*}{$-6,187$} & \multirow{2}{*}{0,00} \\
\hline & 5 yıldızlı & 135 & 4,007 & 0,716 & & \\
\hline
\end{tabular}

Tablo 5’e göre araştırmaya katulanların lider iletişim algısı işletmenin yıldız durumuna göre anlamlı farklılık göstermektedir. 5 yıldızlı otel işletmelerinde çalışan katılımcıların, 4 yldızlı otel işletmelerinde çalışan kathlımclara göre lider iletişim algısının yüksek olduğu saptanmıștır $(p>0,05)$. İş performansı değișkenine ait değerlerde anlamlı bir fark görülmemiștir $(p>0,05)$. İș tatmini değișkeni ile yıldız sayısı arasında anlamlı bir farklılık tespit edilmiștir. 5 yıldızlı otel işletmelerinde çalışanların iş tatmini algllarının 4 ylldızlı otel işletmelerinde çalışanlara göre daha yüksek olduğu görülmüștür ( $p>0,05)$.

Tablo 6. Araştırmaya Katılanların Liderlik İletişimi, İş Performansı ve İş Tatmini Algısı İle Yaş Değişkeni Arasındaki Farklılığa İlişkin Anova Testi Sonuçları

\begin{tabular}{|c|c|c|c|c|c|c|c|}
\hline & & $\mathrm{n}$ & $\bar{x}$ & S. S. & $\mathrm{F} / \mathrm{t}$ & $\mathrm{p}$ & $\begin{array}{c}\text { Tukey } \\
\text { HSD }\end{array}$ \\
\hline \multirow{6}{*}{ Liderlik İletişimi } & 25 yaș ve altı ${ }^{a}$ & 37 & 2,22 & 1,07 & \multirow{6}{*}{23,29} & \multirow{6}{*}{0,00} & \multirow{6}{*}{$\begin{array}{c}\text { a-b, a-c, } \\
\text { a-d, a-e, } \\
\text { a-f, b-d, } \\
\text { b-e, b-f, } \\
\text { c-d, c-e, } \\
\text { c-f }\end{array}$} \\
\hline & 26-30 yaș b & 66 & 3,09 & 1,09 & & & \\
\hline & 31-35 yaș ${ }^{c}$ & 64 & 3,11 & 1,12 & & & \\
\hline & 36-40 yaş ${ }^{d}$ & 42 & 3,74 & 0,77 & & & \\
\hline & 41-45 yaș e & 46 & 4,21 & 0,84 & & & \\
\hline & 46 yaș ve üzeri ${ }^{f}$ & 25 & 4,27 & 0,88 & & & \\
\hline \multirow{6}{*}{ İş Performansı } & 25 yaș ve altı ${ }^{a}$ & 37 & 4,31 & 0,83 & \multirow{6}{*}{3,98} & \multirow{6}{*}{0,00} & \multirow{6}{*}{ a-e, b-e, } \\
\hline & 26-30 yaș ${ }^{b}$ & 66 & 4,39 & 0,95 & & & \\
\hline & 31-35 yaş c & 64 & 4,46 & 0,56 & & & \\
\hline & $36-40$ yaș ${ }^{d}$ & 42 & 4,61 & 0,50 & & & \\
\hline & 41-45 yaș e & 46 & 4,80 & 0,28 & & & \\
\hline & 46 yaș ve üzeri ${ }^{f}$ & 25 & 4,81 & 0,43 & & & \\
\hline \multirow{6}{*}{ İş Tatmini } & 25 yaș ve altı a & 37 & 2,99 & 0,90 & \multirow{6}{*}{36,92} & \multirow{6}{*}{0,00} & \multirow{6}{*}{$\begin{array}{c}\text { a-b, a-c, } \\
\text { a-d, a-e, } \\
\text { a-f, b-d, } \\
\text { b-e, b-f, } \\
\text { c-d, c-e, } \\
\text { c-f, d-e, } \\
\text { d-f }\end{array}$} \\
\hline & 26-30 yaș b & 66 & 3,42 & 0,66 & & & \\
\hline & 31-35 yaș c & 64 & 3,53 & 0,60 & & & \\
\hline & $36-40$ yaş ${ }^{d}$ & 42 & 4,00 & 0,34 & & & \\
\hline & 41-45 yaș e & 46 & 4,39 & 0,38 & & & \\
\hline & 46 yaș ve üzeri ${ }^{f}$ & 25 & 4,45 & 0,43 & & & \\
\hline
\end{tabular}


Serdar Çöp, Ali Doğanay, "Algılanan Liderlik İletişiminin İş̧ Performansı ve İş Tatminine Etkisi: 4 ve 5 Yıldızlı Otel Çalışanları Üzerine Bir Araștırma”, İstanbul Gelișim Üniversitesi Sosyal Bilimler Dergisi, 7 (1), Nisan 2020, ss. 34-49.

Tablo 6'da araştırmaya katılanların liderlik iletişimi, iş performansı ve iş tatmini algısının yaş değișkenine göre anlamlı farlılık oluşturup oluşturmadığına ilişkin 0,05 anlamlılık seviyesinde yapılan anova testi sonuçları görülmektedir. Buna göre otel işletmesi çalışanlarının lider iletişim algılarının yaş değișkenine göre farklılık gösterdiği saptanmıştır. Farklılı̆ın hangi ikiliden kaynaklandığını belirlemek için yapılan Tukey testine göre 25 ve alt yaş grubunun, 26-30, 31-35, 36-40, 41-45, 46 yaş ve üzeri grupla, 26-30 yaş grubunun 36-40, 45 ve üzeri yaş grubu ile, 31-35 yaş grubunun 36-40, $41-45$ ve 46 ve üzeri yaş grubuyla arasında anlamlı farlılık tespit edilmiștir ( $>>0,05)$.

Otel çalş̧anlarının performans algllarının yaş değişkenine göre anlamlı farlılık oluşturup oluşturmadığına ilişkin sonuçlar incelendiğinde ise performans değişkeniyleyaş değișkeni arasında anlamlı farklılık görülmüştür. Farklılığn hangi ikiliden kaynaklandığını belirlemek için yapılan Tukey testine göre 25 ve altı yaş grubuyla 41-45 yaş grubu arasında anlamlı bir fark; 26-30 yaş grubu ile 41-45 yaşgrubu arasında anlamlı farklılık tespit edilmiştir ( $p>0,05)$.

Otel çalıșanlarının iș tatmini alglarının yaș değișkenine göre anlamlı farklılık olușturup oluşturmadığına ilişkin sonuçlar incelendiğinde her iki değişken arasında anlamlı farklılık olduğu görülmüsstür. Farklılığın hangi ikiliden kaynaklandığını belirlemek için yapılan Tukey testine göre 25 ve altı yaş grubuyla $26-30,31-35,36-40,41-45,46$ yaș ve üzeri yaş grubu arasında, 26-30 yaș grubu ile 36-40, 41-45, 46 ve üzeri yaş grubu arasında, 31-35 yaş grubu ile 36-40, 41-45 ve 46 ve üzeri arasında, 36-40 yaş grubu ile ise 41-45 ve 46 ve üzeri grup arasında anlamlı farkllık tespit edilmiștir $(p>0,05)$. Elde edilen verilerin analizinde genel olarak yaş değerinin artması ile liderlik iletişimi, iş performansı ve iş tatmini algısının arttğı görülmektedir.

Tablo 7. Araştırmaya Katılanların Liderlik İletişimi, İş Performansı ve İş Tatmini Algısı ile Pozisyon Değişkeni Arasındaki Farklılığa İlişkin Anova Testi Sonuçları

\begin{tabular}{|c|c|c|c|c|c|c|c|}
\hline & & $\mathrm{n}$ & $\bar{x}$ & S. S. & $\mathrm{F} / \mathrm{t}$ & $\mathrm{p}$ & $\begin{array}{c}\text { Tukey } \\
\text { HSD }\end{array}$ \\
\hline \multirow{3}{*}{ Liderlik İletişimi } & İşgören a & 186 & 3,00 & 1,08 & \multirow{3}{*}{40,98} & \multirow{3}{*}{0,00} & \multirow{3}{*}{$\begin{array}{c}\text { a-b, a-c } \\
\text { b-c, }\end{array}$} \\
\hline & $\begin{array}{l}\text { Orta düzey } \\
\text { yönetici b }\end{array}$ & 76 & 3,91 & 1,04 & & & \\
\hline & $\begin{array}{l}\text { Üst düzey } \\
\text { yönetici c }\end{array}$ & 18 & 4,87 & 0,29 & & & \\
\hline \multirow{3}{*}{ İş Performansı } & İşgören a & 186 & 4,42 & 0,77 & \multirow{3}{*}{8,44} & \multirow{3}{*}{0,00} & \multirow{3}{*}{$\mathbf{a}-\mathbf{b}, \mathbf{a}-\mathbf{c}$, } \\
\hline & $\begin{array}{l}\text { Orta düzey } \\
\text { yönetici }^{\text {b }}\end{array}$ & 76 & 4,70 & 0,40 & & & \\
\hline & $\begin{array}{l}\text { Üst düzey } \\
\text { yönetici c }\end{array}$ & 18 & 4,95 & 0,17 & & & \\
\hline \multirow{3}{*}{ İş Tatmini } & İşgören a & 186 & 3,47 & 0,71 & \multirow{3}{*}{53,11} & \multirow{3}{*}{0,00} & \multirow{3}{*}{$\begin{array}{c}\text { a-b, a-c, } \\
\text { b-c, }\end{array}$} \\
\hline & $\begin{array}{l}\text { Orta düzey } \\
\text { yönetici b }\end{array}$ & 76 & 4,10 & 0,54 & & & \\
\hline & $\begin{array}{l}\text { Üst düzey } \\
\text { yönetici c }\end{array}$ & 18 & 4,84 & 0,14 & & & \\
\hline
\end{tabular}

Tablo 7'de araştırmaya katılan otel çalışanlarının liderlik iletişim algları, iş performansı ve iş tatmini algısının pozisyona göre anlamlı farlılık olușturup olușturmadığına ilişkin 0,05 seviyesinde yapılan Anova testi sonuçları görülmektedir. Buna göre otel çalışanlarının lider iletişim 
Serdar Çöp, Ali Doğanay, "Algılanan Liderlik İletişiminin İş̧ Performansı ve İş Tatminine Etkisi: 4 ve 5 Yıldızlı Otel Çalışanları Üzerine Bir Araştırma”, İstanbul Gelişim Üniversitesi Sosyal Bilimler Dergisi, 7 (1), Nisan 2020, ss. 34-49.

alglarının pozisyon değişkenine göre farkllık gösterdiği tespit edilmiștir. Farklllı̆ın hangi ikiliden kaynaklandığını belirlemek için yapılan Tukey testine göre katılımcllar ile orta düzey ve üst düzey yöneticiler arasında, orta düzey yöneticiler ile de üst düzey yöneticiler arasında anlamlı farklılık saptanmıştır ( $\mathrm{p}>0,05)$.

Otel çalışanlarının performans alglarının pozisyona göre anlamlı farklılık oluşturup olușturmadığına ilișkin sonuçlar incelendiğinde performans değișkeniyle pozisyon arasında anlamlı farklılık tespit edilmiștir. Farklılığın hangi ikiliden kaynaklandığını belirlemek için yapılan Tukeytestinegöre işgörenler ile orta düzeyyöneticiler ve üst düzeyyöneticiler arasındaanlamlı fark tespit edilmiștir ( $\mathrm{p}>0,05)$.

Otel çalışanlarının iş tatmini alglarının pozisyona göre anlamlı farklllk oluşturup oluşturmadığına ilişkin sonuçlar incelendiğinde her iki değișken arasında anlamlı farklılık olduğu görülmüștür. Farklılığın hangi ikiliden kaynaklandığını belirlemek için yapılan Tukey testine göre işgörenler ile orta düzey ve üst düzey yöneticiler arasında, orta düzey yöneticiler ile de üst düzey yöneticiler arasında anlamlı farkllık görülmüștür $(\mathrm{p}>0,05)$.

\section{Tablo 8. Araştırmaya Katılanların Liderlik İletişimi, İş Performansı ve İş Tatmini Algısı ile İşletmedeki Görev Süresi Arasındaki Farklılığa İlişkin Anova Testi Sonuçları}

\begin{tabular}{|c|c|c|c|c|c|c|c|}
\hline & & $\mathrm{n}$ & $\bar{x}$ & S. S. & $\mathrm{F} / \mathrm{t}$ & $\mathrm{p}$ & $\begin{array}{l}\text { Tukey } \\
\text { HSD }\end{array}$ \\
\hline \multirow{5}{*}{ Liderlik İletişimi } & 1 yıldan az ${ }^{a}$ & 40 & 2,61 & 1,12 & \multirow{5}{*}{14,42} & \multirow{5}{*}{0,00} & \multirow{5}{*}{$\begin{array}{l}a-b, a-c \\
a-d, a-e, \\
b-d, b-e \\
c-d, c-e,\end{array}$} \\
\hline & $1-5$ yll b $^{\mathrm{b}}$ & 131 & 3,27 & 1,17 & & & \\
\hline & $6-10 \mathrm{yll} \mathrm{c}^{\mathrm{c}}$ & 77 & 3,43 & 1,03 & & & \\
\hline & $11-15 \mathrm{yll}^{\mathrm{d}}$ & 20 & 4,57 & 0,51 & & & \\
\hline & 15 yll ve üzeri $\mathrm{e}$ & 12 & 4,47 & 0,88 & & & \\
\hline \multirow{5}{*}{ İş Performansı } & 1 yıldan az ${ }^{\text {a }}$ & 40 & 4,36 & 0,76 & \multirow{5}{*}{1,96} & \multirow{5}{*}{0,101} & \multirow{5}{*}{-} \\
\hline & $1-5$ yll b $^{\mathrm{b}}$ & 131 & 4,51 & 0,72 & & & \\
\hline & $6-10 \mathrm{yll}^{\mathrm{c}}$ & 77 & 4,54 & 0,65 & & & \\
\hline & $11-15 y_{1 l}{ }^{d}$ & 20 & 4,83 & 0,24 & & & \\
\hline & 15 yll ve üzeri e & 12 & 4,77 & 0,59 & & & \\
\hline \multirow{5}{*}{ İş Tatmini } & 1 yıldan az ${ }^{\text {a }}$ & 40 & 3,07 & 0,89 & \multirow{5}{*}{19,34} & \multirow{5}{*}{0,00} & \multirow{5}{*}{$\begin{array}{l}a-b, a-c \\
a-d, a-e \\
b-d, b-e \\
c-d, c-e\end{array}$} \\
\hline & $1-5$ yll b $^{b}$ & 131 & 3,71 & 0,72 & & & \\
\hline & 6-10 yll c & 77 & 3,79 & 0,54 & & & \\
\hline & $11-15$ yll d $^{d}$ & 20 & 4,34 & 0,44 & & & \\
\hline & 15 yll ve üzeri e & 12 & 4,67 & 0,40 & & & \\
\hline
\end{tabular}

Tablo 8'de araștırmaya katılan otel çalışanlarının liderlik iletişim algları, iș performansı ve iş tatmini değişkeninin işletmedeki görev süresi değișkenine göre anlamlı farklıllk oluşturup olușturmadığına ilişkin 0,05 anlamlılık seviyesinde yapılan Anova testi sonuçları görülmektedir. Buna göre otel çalışanlarının lider iletişim algllarının pozisyon değişkenine göre farkllık gösterdiği tespitedilmiştir. Farklılığın hangi ikiliden kaynaklandığını belirlemekiçin yapılan Tukey testinegöre 1 yıldan az görev süresine sahip çalışanların lider iletişim algılarının 1-5, 6-10,11-15 ve 15 yıl üzeri görev süresine sahip olanlara göre farklllık gösterdiği, 1-5 yl görev süresine sahip çalışanların; 1115 ve 15 yll ve üzeri çalışanlara göre farkllllk gösterdiği belirlenmiștir. 6-10 yll görev süresine sahip çalışanların ise 11-15 ve 15 yll ve üzeri görev süresine sahip olanlara göre anlamlı farklllıkgösterdiği saptanmıștır $(p>0,05)$. Otel çalışanlarının performans algısıyla işletmedeki görev süresi arasında anlamlı bir farklılık tespit edilememiștir. 
Otel çalışanlarının iş tatmini alglarının işletmedeki görev süresi değişkenine göre anlamlı farklılık olușturup olușturmadığına ilișkin sonuçlarincelendiğinde her iki değișken arasında anlamlı farklılı olduğu görülmüștür. Farklllığın hangi ikiliden kaynaklandığını belirlemek için yapılan Tukey testine göre 1 ylldan az görev süresi olanlar ile 1-5 yll, 6-10 yl, $11-15$ yll 15 yll ve üzeri görev süresi olanlar arasında; 1-5 yl görev süresi olan ile 11-15 yl, 15 yll ve üzeri görev süresi olanlar arasında, 6-10 yll görev süresi olan ile de $11-15$ ve 15 yll ve üzeri görev süresi olanlar arasında anlamlı farklılık saptanmıştır ( $\mathrm{p}>0,05)$.

\section{Tablo 9. Araştırmaya Katılanların Liderlik İletişimi, İş Performansı ve İş Tatmini Algısı ile Eğitim Durumu Arasındaki Farklıı̆ga İlişkin Anova Testi Sonuçları}

\begin{tabular}{|c|c|c|c|c|c|c|c|}
\hline & & $\mathrm{n}$ & $\bar{x}$ & s. S. & $\mathrm{F} / \mathrm{t}$ & $\mathrm{p}$ & $\begin{array}{c}\text { Tukey } \\
\text { HSD }\end{array}$ \\
\hline \multirow{5}{*}{ Liderlik İletişimi } & İlköğretima & 54 & 2,94 & 1,26 & \multirow{5}{*}{5,67} & \multirow{5}{*}{0,00} & \multirow{5}{*}{$\begin{array}{l}\text { a-d, a-e, } \\
\text { b-d, b-e, }\end{array}$} \\
\hline & Lise $^{b}$ & 101 & 3,22 & 1,22 & & & \\
\hline & Önlisans ${ }^{c}$ & 57 & 3,44 & 1,17 & & & \\
\hline & Lisans $^{\mathrm{d}}$ & 56 & 3,77 & 0,92 & & & \\
\hline & Lisansüstüe & 12 & 4,20 & 0,53 & & & \\
\hline \multirow{5}{*}{ İş Performansı } & İlköğretima & 54 & 4,35 & 0,99 & \multirow{5}{*}{1,81} & \multirow{5}{*}{0,126} & \multirow{5}{*}{-} \\
\hline & Lise $^{b}$ & 101 & 4,51 & 0,69 & & & \\
\hline & Önlisans ${ }^{c}$ & 57 & 4,59 & 0,53 & & & \\
\hline & Lisans $^{\mathrm{d}}$ & 56 & 4,68 & 0,39 & & & \\
\hline & Lisansüstüe & 12 & 4,62 & 0,44 & & & \\
\hline \multirow{5}{*}{ İş Tatmini } & İlköğretima & 54 & 3,55 & 0,94 & \multirow{5}{*}{1,37} & \multirow{5}{*}{0,244} & \multirow{5}{*}{-} \\
\hline & Lise $^{b}$ & 101 & 3,70 & 0,84 & & & \\
\hline & Önlisans ${ }^{c}$ & 57 & 3,79 & 0,67 & & & \\
\hline & Lisans $^{\mathrm{d}}$ & 56 & 3,85 & 0,51 & & & \\
\hline & Lisansüstüe & 12 & 3,88 & 0,42 & & & \\
\hline
\end{tabular}

Tablo 9'da araştırmaya katılan otel çalışanlarının liderlik iletişim algları, iş performansı ve iş tatmini değişkeninin eğitim durumuna göre anlamlı farkllık oluşturup oluşturmadığına ilişkin 0,05 seviyesinde yapılan Anova testi sonuçları görülmektedir. Buna göre otel çalışanlarının lider iletişim alglarının eğitim durumuna göre farklılık gösterdiği saptanmıștır. Farklılı̆̆ın hangi ikiliden kaynaklandığını belirlemek için yapılan Tukey testine göre ilköğretim mezunlarının lider iletişim alglarının lisans ve lisansüstü mezunların lider iletișim algllarıyla, lise mezunu çalıșanların iletișim algılarıyla lisans ve lisansüstü mezunlarının lider iletişim algları arasında anlamlı farklılık görülmüștür $(p>0,05)$. Performans ve iş tatmini değişkenleri ile otel işletmeleri çalışanlarının eğitim durumları arasında anlamlı bir fark tespit edilmemiștir ( $p>0,05)$. Fakat elde edilen bulgular incelendiğinde; iş performansı ve iş tatminine ilişkin algının, eğitim seviyesi yükseldikçe arttı̆gifade edilebilir. 
Tablo 10. Araştırmaya Katılanların Liderlik İletişimi Algısının İş Performansı ve İş Tatmini Üzerindeki Etkisine İlişkin Regresyon Analizi Sonuçları

\begin{tabular}{|c|c|c|c|c|c|c|c|c|}
\hline Model & $\begin{array}{l}\text { Bağımsız } \\
\text { Değișken }\end{array}$ & B & St. Hata & $\mathbf{t}$ & p & $\mathbf{R}$ & $\mathbf{R}^{2}$ & $\begin{array}{c}\text { F/ } \\
\text { p(sig.) }\end{array}$ \\
\hline \multirow{2}{*}{ İş Performansı } & Sabit & 3,946 & 0,119 & 33,284 & 0,000 & \multirow{2}{*}{0,303} & \multirow{2}{*}{0,092} & \multirow{2}{*}{$0,000^{*}$} \\
\hline & $\begin{array}{c}\text { Lider İletişim } \\
\text { Algisl }\end{array}$ & 0,176 & 0,033 & 5,294 & 0,000 & & & \\
\hline \multirow{2}{*}{ İş Tatmini } & Sabit & 2,587 & 0,118 & 21,966 & 0,000 & \multirow{2}{*}{0,526} & \multirow{2}{*}{0,276} & \multirow{2}{*}{$0,000^{*}$} \\
\hline & $\begin{array}{c}\text { Lider İletişim } \\
\text { Algisl }\end{array}$ & 0,340 & 0,033 & 10,300 & 0,000 & & & \\
\hline
\end{tabular}

Tablo 10'da liderlik iletişim algısının iş performansı ve iş tatmini üzerindeki etkisine ilişkin regresyon analizi sonuçları verilmiştir. Tabloya göre lider iletişim algısının iş performansı üzerinde orta düzeyde $(R=0,303)$ ve anlamlı bir etkiye $(p=0,000)$ sahip olduğu tespit edilmiștir. Bağımsız değişkenin iş performansının \% 0,92'sini açıkladığı söylenebilir. Performans değișkeni modele $\mathrm{B}=3,946 ; \mathrm{t}=33,284 \quad \mathrm{p}=0,000)$ oranında katkı sunmaktadır. Buradan lider iletişim algisı değişkeninin boyutunda meydana gelen bir birimlik artışın performans algısını 3,946 birim arttracağ ifade edilebilir.

İş tatmini ile ilgili verilere bakıldığında ise lider iletişim algısının iş tatmini üzerinde orta düzeyde $(\mathrm{R}=0,526)$ ve anlamlı bir etkiye $(\mathrm{p}=0,000)$ sahip olduğu görülmektedir. Bağımsız değișkenin iș tatmininin \%27'sini açlkladığı söylenebilir. İș tatmini değișkeni modele $\mathrm{B}=2,587$; $\mathrm{t}=21,966,(\mathrm{p}=0,000)$ oranında katkl sunmaktadır. Buradan lider iletişim algısı değișkeninin boyutunda meydana gelen bir birimlik artsşın iș tatmini algısını 2,587 birim arttıracağı ifade edilebilir. Otel işletmelerinde çalışanların, lider iletişim algılarının iş tatminini ve iş performansını oldukça önemli düzeyde etkilediği tespit edilmiştir.

Elde edilen bu bulgulara göre hipotezler;

$\mathbf{H}_{\mathbf{1}}$ "Çalışanların Lider İletişim Algısının İş Tatmini üzerinde istatistiki açıdan anlamlı etkisi vardır" hipotezi red edilememiștir.

$\mathbf{H}_{2}$ "Çalıșanların Lider İletişim Algısının İş Performansı üzerinde istatistiki açıdan anlamlı bir etkisi vardır" hipotezi red edilememiștir.

\section{SONUÇ}

Araştırma kapsamında bireysel özellikler ile liderlik iletişimi, iş performansı ve iş tatmini arasındaki farkllıklara ilişkin sonuçlar ortaya konulmaya çalışılmıştır. Elde edilen bulgulardan liderlik iletişimi, iş tatmini ve iş performansı algısının yaș, çalışılan pozisyon, cinsiyet, görev süresi ve eğitim durumuna göre farkllık gösterdiği sonucuna varılmıștır.

Otel işletmelerinde yapılan bu araştırmayla lider iletişiminin iş yaşamının yadsınamaz parçası olan, iş performansı ve iş tatminine etkilerinin belirlenmesi amaçlanmıştr. Böylece emekyoğun otel işletmelerinde, lider iletişiminin iş performansı ve iş tatmini üzerinde hangi düzeyde etkili olduğu açlklanmaya çalışılmıştır. Araştırmaya kathlan otel işletmesi çalışanlarının lider iletişim algısının iş performansına ve iş tatminine etkisi için regresyon analizi yapılmıștır. Bu analiz sonucunda lider iletişim algısının çalışanların iş performansı ve iş tatmini üzerinde pozitif yönlü ve anlamlı etkisi olduğu görülmüștür.

Otel çalışanlarının sahip olduğu fikir, bilgi ve önerileri paylaşmaları ișletmeleri bulundukları noktadan daha da ileri taşıyacaktır. Örgütlerde çalsşanların iletişim içerisinde olmaları, yaptıkları işe ilişkin astları ya da üstleri ile fikir alışverişinde bulunmaları gerekmektedir. 
Serdar Çöp, Ali Doğanay, "Algılanan Liderlik İletişiminin İş̧ Performansı ve İş Tatminine Etkisi: 4 ve 5 Yıldızlı Otel Çalıșanları Üzerine Bir Araştırma”, İstanbul Gelișim Üniversitesi Sosyal Bilimler Dergisi, 7 (1), Nisan 2020, ss. 34-49.

Fikir alış verişi için ortamların yaratıldığı, iletişim kanallarının sürekli açık tutulduğu işletmelerde, iş performansı ve iş tatmini dolayısıyla da müşteri tatmini yüksek olacaktır (Dyne vd., 2003, s. 1369). Otel işletmelerinde güçlü lider iletişim algısının varlığı, hedefe odaklanmış, iş tatmini ve iş performansı yüksek çalışanlar anlamına gelmektedir. Bu çalışanlar, ișletmelerin varlıklarını devam ettirmelerinde önemli bir unsur olarak görülen beșeri sermayedir. Bu sermaye otel ișletmelerinde sürdürülebilirliğin temelidir.

Sökmen (2019, s. 986) tarafından yapılan araștırmada iş tatmininin müşteri tatmini ile birlikte gerçekleștiğine değinilmiştir. Otellerde çalışanların tatmini, otellerin varlık nedeni olan müşterilerinin tatmini anlamına gelmektedir. Buradan gerek iş tatmini gerekse iş performansi için otellerde güçlü lider iletişim algısına ilişkin farkındalık oluşturmak gerekmektedir. Çalışanların işten ayrılma, düşük performans, tükenmişlik davranışı sergilemelerinde yöneticileriyle yaşadıkları sorunlar önemli bir yer tutmaktadır. Yöneticilerin çalıșanlarını yok sayması, onlara değer vermemesi, her șeyin başlangıç ve bitiş noktası olarak kendilerini görmeleri, çalışanların kararlara kathımlarını sağlamamaları, örgüte gönülden bağlanmalarına, ișlerini sahiplenmelerine engel olmaktadır. Bunun için otellerde örgüt kültürü haline gelecek, güçlü iletişim ağlarının oluşturulması üst yönetimin görevidir. Otel işletmelerinde periyodik olarak yapılacak paydaş toplantıları, yayınlanmıș ve uygulanan açık kapı politikaları, iletișim stratejileri, bilgi teknolojilerine bağlı iletişim sistemlerinin kurulmasının iş performansı ve iş tatmini üzerinde önemli etkileri olacaktır.

Araştırma sonuçlarında da görüldüğü gibi liderlerin çalışanlarıyla kurdukları iletişim onların iş performansını ve iş tatminini arttırmaktadır. Dolayısıyla iyi işleyen bir yönetici-çalışan iletişim sistemi çalışanların ișlerini icra ederken belirsizlik yașamalarına engel olacaktır. Rutinveya beklenmeyen durum karșısında nasıl hareket edeceği veya kimden fikir alacağı konusunda sıkıntı yaşayan çalışanlar, böylesi bir dönemde rehbere ihtiyaç duyarlar. Bu dönemdeki en iyi rehberler o kişilerin liderleridir. Dolayısıyla çalıșanların liderleriyle, açık, rahat, kesin, samimi, doğru bir iletişim kurabilecekleri ortamlar hazirlanmalıdır.

İşletmelerin faaliyet politikalarında șeffaflık, hesap verilebilirlik, topluma ve çevreye katkı önemli unsurlar olarak karşımıza çıkmaktadır. Bu unsurların gerçekleștirilebilmesinde liderlik iletişimi temel oluşturacaktır. İşletmelerin faaliyetlerinde güçlü lider iletişimi için hızlı ve güvenilir bilgi akışının, kararlara katılımın sağlanması gerekmektedir. Tüm bu hususlar çerçevesinde liderlik iletişiminin örgütlerde güçlendirilmesi, iş performansının ve iş tatmininin önemli belirleyicisidir.

\section{KAYNAKÇA}

ARMSTRONG M. (1996). Employee Reward. London: Institute of Personnel and Development (IPD) House.

ASLANBAY A. (2018) Kurum içi iletişimin önemi. Erişim Tarihi: 29.08.2018.

http://www.messegitim.com.tr/ti/347/0/Kurum-Ici-Iletisimin-Onemi

BAKAN, İ. (2009). Liderlik Tarzlar ile Örgüt Kültürü Türleri Arasındaki Illişkiler: Bir Alan Çalışması. Ankara: TiSK Akademi, 4 (7), 138-172.

BARON A. B. \&. GREENBERG J. (2000). Leadership in Organizations, Behavior in

Organizations, New Jersey: Prentice-Hall Inc., Seventh Edition.

BAȘARAN, E. (1991). Örgütsel Davranış, Ankara: Gül Yayınevi.

BIÇAKÇI, İ. (2006). Illetişim ve Halkla İlişkiler. İstanbul: Mediacat.

BOLTON, T. (1997). Human Resource Management: An introduction. Massachusetts:

Blackwell Publishers.

CANMAN, D. (1995). Çağdaş Personel Yönetimi. Ankara: Türkiye ve Orta Doğu Amme İdaresi Enstütüsü. 
Serdar Çöp, Ali Doğanay, "Algılanan Liderlik İletişiminin İş̧ Performansı ve İş Tatminine Etkisi: 4 ve 5 Yıldızlı Otel Çalışanları Üzerine Bir Araştırma”, İstanbul Gelişim Üniversitesi Sosyal Bilimler Dergisi, 7 (1), Nisan 2020, ss. 34-49.

CEMALOĞLU, N. (2002). Öğretmen Performansının Artırılmasında Okul Yöneticisinin Önemi. Milli Eğitim Kültür Sanat. 153-154.

CUMMINGS, T.G. \& WORLEY, C.G (1997) Organization Development and Change. United States of America, International Thompson Publishing.

ÇÖL, G. (2008). Alglanan Güçlendirmenin İsgören Performansı Üzerine Etkileri, Doğuş Üniversitesi Dergisi, 9 (1), 35-46.

DAVIS, K. (1988). İşletmede İnsan Davranışı-Örgütsel Davranış, Çev. Kemal Tosun, İstanbul İstanbul Üniversitesi İșletme Fakültesi Yayını.

DYNE, L. V., ANG, S., BOTERO, I. C. (2003). Conceptualizing employee silence and employee voice as multidimensional constructs. Journal of Management Studies, 40(6), 13591392.

ERDOĞAN, İ. (1991). İşletmelerde Personel Seçimi ve Başarı Değerleme Teknikleri, İstanbul: İșletme Fakültesi Yayın No. 248.

ERGÜN, E. (2018). Lider Desteğinin Lider Üye Etkileșimine (LÜE) ve İş Tatminine Etkileri, Atatürk Üniversitesi İktisadi ve İdari Bilimler Dergisi, 32(1), 177-193.

ERKUȘ, A., ve GÜNLÜ E., (2009). İletişim tarzının ve sözsüz iletişim düzeyinin çalışanların iş performansına etkisi: beș yıldızlı otel ișletmelerinde bir araştırma. Anatolia: Turizm Araștirmaları Dergisi. Cilt 20, Sayn 1.7-24. Erişim adresi: http://dergipark.gov.tr/download/article-file/154380

ERSEN, H. (1997). Toplam Kalite ve İnsan Kaynakları Yönetim Ilișkisi, İstanbul.

ERYEŞIL, K., İRAZ Rıfat. (2017). Liderlik Tarzları İle Örgütsel Bağllık Arasındaki İlişkinin İncelenmesine Yönelik Bir Alan Araștırması, Selçuk Üniversitesi Sosyal Bilimler Meslek Yüksekokulu Dergisi, Cilt: 20, Sayı: 2.129-139.

FINDIKÇI, İ.. (2000). İnsan Kaynakları Yönetimi. İstanbul: Alfa Yayınları.

GRAY, J., LAIDLAW, H. (2002). Part Time Employment And Communication Satisfaction in An Australian Retail Organization. Employee Relations. 24(2): 211-228.

HELVACI, M.A. (2002). Performans Yönetim Sürecinde Performans Değerlendirmenin

Önemi, Ankara Üniversitesi Ĕ̆itim Bilimleri Fakültesi Dergisi, 2002, Cilt, 35, Sayı :1-2, s. 155-169. Yayınları. KALKANDELEN, H.(1997). Örgütlerde Yeniden Yapılanma ve Norm Kadro. Ankara: Anı

KAYA, İ. (2007). Otel İşletmeleri İşgörenlerinin İş Tatminini Etkileyen Faktörler:

Geliştirilen Bir İș Tatmin Ölçeği, Anadolu Üniversitesi Sosyal Bilimler Dergisi, 7(2), 355-372. KOÇEL, T., (2005), İşletme yöneticiliği İstanbul: Arıkan..

KÖK, S.B. (2006). İ̧ Tatmini Ve Örgütsel Bağlllı̆ın İncelenmesine Yönelik Bir Araştırma, İktisadi ve İdari Bilimler Dergisi, 2006, Cilt: 20, Sayl: 1. 291-310.

MINER, J. B. (1992). Industrial-Organizational Psychology, Singapore: Mcgraw-Hill Inc. MUSTAFFA, L.S.; BAKAR, H. A., MOHAMAD B. (2010). The Supervisory CommunicationCommitment to Workgroup Model: Example on a Malasian OrganizationçJournal of US-China Public Administration. 7(1): 13-23.

NEWSTROM, J.W. ve KEITH D. (1997). Organizational Behavior: Human Behaviour at

Work. USA: McGraw Hill Companies, Inc. OSHAGBEMI, T. (1997). The Influence of Rank on The Job Satisfaction of Organizational Members. Journal of Managerial Psychology. Vol 12. 8. 511-519. OSKAY, Ü. (2016). Illetişimin ABC'si, İstanbul: Inkılap, PALMER, M., WINTERS, K. (1993) Insan Kaynakları. Çev: Doğan Şahiner, İstanbul: Rota Yayınları.

PUGH, D.(1991). Organizational Behaviour. Prentice Hall Interneational (UK) Ltd. ROBBINS, P.S. \& COULTER M. (2003). Updates Management 2003, New Jersey, Prentice

Hall. 
Serdar Çöp, Ali Doğanay, "Algılanan Liderlik İletişiminin İş̧ Performansı ve İş Tatminine Etkisi: 4 ve 5 Yıldızlı Otel Çalıșanları Üzerine Bir Araștırma”, İstanbul Gelișim Üniversitesi Sosyal Bilimler Dergisi, 7 (1), Nisan 2020, ss. $34-49$.

SCHNEIDER F.M, MAIER M, LOVREKOVIC S, RETZBACH A., (2015). The Perceived Leadership Communication Questionnaire (PLCQ): Development and Validation, The Journal of Psychology. 149 (2), 175-192.

SMITH, J. M., FIGGINS, S.G, JEWISS, M., KEARNEY, P. E. (2018). Investigating Inspirational Leader Communication In An Elite Team Sport Context, International Journal of Sports Science \& Coaching, 13(2), 213-224.

SÖKMEN, A. (2019). Örgütsel Özdeșleșme, Örgütsel Bağlllık ve İș Tatmini İlișkisi: Otel İşletmelerinde Bir Araștirma, Journal of Tourism and Gastronomy Studies, 7(2), 980-990.

STAM, D., KNIPPENBERG, D. V., WISSE, B., PIETERSE, A. N. (2018). Motivation in Words: Promotion- and Prevention-Oriented Leader Communication in Times of Crisis, Journal of Management, 44(7), 2859-2887.

TAPLIN, I.M., WINTERTON, J. (2007). The Importance of Management Style in Labor Retention. International Journal of Sociology and Social Policy, 27(1/2): 5-18.

THOMBSON B.L. (2002), Yeni Yöneticinin El Kitabı, Çev. Vedat. D. Diker, İstanbul: Hayat Yayınları.

TORRINGTON, D.ve HALL, L. (1995). Personel Management. HRM in Action. London: Prentice Hall.

TUTAR, H. vd., (2003). Genel ve Teknik Illetişim, Ankara: Nobel Yayın.

VROOM, V. H. (1967) Work and Motivation. New Jersey: John Wiley and Sons Inc.

WEISS, D.J., DAWIS, R.V., ENGLAND, G.W., ve LOFQUIST, L. H. (1967). Manual for The

Minnesota Satisfaction Questionnaire (Minnesota Studies in Vocational Rehabilitation, No. 22),

Minneapolis: University of Minnesota.

YAMMARINO, F.J., DANSEREAU F., (2009). Multi-level Issues in Organizational Behavior and Leadership, Outstanding Leadership, Charismatic, Ideologıcal, and Pragmatic Leadership: An Examination of Multi-Level Influences on Emergence and Performance, Abstract Vol. 8.

\section{Summary}

Nowadays, the importance of leadership in the investment made to human beings is increasing day by day as the competition increases and the enterprises cannot gain superiority with only the financial resources. It is worth to examine the importance of leadership and communication not only as a style or system, but also to reveal the importance of these phenomena in relations with subordinates. Considering that the communication style used by the leaders during communication with their subordinates and the communication perception formed in the subordinates affect theirjob satisfaction and performance, the role of these variables on the success of the organization is noteworthy. The performance and job satisfaction of the employees who have to provide uninterrupted service in the hotel businesses, which have a very important place in the service sector, is very important in terms of the organization's performance. This study was carried out to determine the extent to which the communication of the leaders or managers in the hotel business with the subordinates changed their job satisfaction and performance and to discuss the results. For this purpose, the scale containing the variables was applied to 280 employees in 5 and 4 star hotels operating in Istanbul. As a result of the analysis, it has been concluded that the leader communication perception has an effect on the performance and job satisfaction of the employees. 